\title{
Fair value accounting and reliability of accounting information of listed firms in Nigeria
}

\author{
Oyebisi Ibidunni $^{{ }^{*}}$ and Wisdom Okere ${ }^{\mathrm{a}}$
}

a Department of Accounting, Bells University of Technology, Ota-Ogun State, Nigeria

\begin{tabular}{l}
\hline C H R O N I C L E \\
\hline Article history: \\
Received August 3, 2018 \\
Received in revised format \\
August 232018 \\
Accepted September 72018 \\
Available online \\
September 72018 \\
\hline Keywords: \\
Fair value accounting \\
Historical cost \\
IFRS \\
Relevance \\
Reliability
\end{tabular}

\section{A B S T R A C T}

\begin{abstract}
This study examined the association between fair value accounting and reliability of accounting information. The study adopted survey research along with quantitative methods. Users of the accounting information represented by corporate investment analysts and corporate portfolio managers were the respondents for the purpose of this study. The population size was one hundred and sixty-one (161) users of accounting information decomposed into one hundred (100) corporate investment analysts and sixty-one (61) corporate portfolio managers. The primary source of data was employed with the structured questionnaire as an instrument used to collect the data. Data was collected through the administration of 161 copies of the questionnaire to both corporate investment analysts and corporate portfolio managers. One hypothesis was formulated and was tested using the Pearson product moment correlation technique at a significant level of $5 \%$ and $10 \%$ while the Statistical Package for Social Science (SPSS) was engaged to analyze the data. Findings revealed a significant association between fair value accounting and reliability of accounting information of the firms in Nigeria. Hence, the study recommended that adequate and regular training programs and conferences on fair value accounting application have to be organized. This is because most of the employees of the companies in Nigeria did not understand how to use fair value in an inactive market, appropriately. Thus, it is of great importance that they were trained to understand different valuations and estimation techniques of fair value; how and when to apply them in the measurement of assets and liabilities in the financial statement.
\end{abstract}

\section{Introduction}

The practice of companies for closing its books of account while preparing and presenting its annual income statement and balance sheet has been accomplished using accounting periodicity for several years. Over the years, organizations have come to learn and accept the concept of Historical Cost Accounting, which is a traditional system based on the double entry principle that reports transaction cost at the original price. While this method of measuring assets and liabilities in the financial statement has several benefits such as objectivity, reliability and ability to provide conclusive evidence, it has however been criticized on the basis that it fails to account for changes in price level of company's assets over a period of time. As a result, assets are presented at prices sometimes lower than the realizable price, thereby leading to a reduction in the reliability and relevance of accounting information. It has also been observed that, it is not a good approach to be used in inflationary market

* Corresponding author.

E-mail address: ogundanaoyebs@gmail.com (O. Ibidunni) 
in addition to which it provides information that are only reliable but not relevant to decision making and it provides medium for profit smoothing and gains trading by managers by hiding excess reserves, amongst others (Betakova et al., 2014). Because of these drawbacks in historical cost accounting, accounting standard setters in 1980 saw a need for a paradigm shift from historical cost accounting to fair value accounting. This shift was further strengthened by various financial scandals that rocked some corporations such as Xerox in 2000, Enron in 2001, Worldcom in 2002 and Pamalat in 2003 and in Nigeria amongst others Oceanic Bank, Intercontinental Bank, Afribank and Cadbury (Okere et al., 2017). This shift to fair value accounting was presumed to bring an improvement over the historical cost accounting and it was believed it would correct the lapses encountered under historical cost accounting. According to IFRS 13, fair value is defined "as the price that would be received to sell an asset or paid to transfer a liability in an orderly transaction between market participants at the measurement date". Fair value is expected to provide financial accounting information with high level of decision-usefulness and information relevance of accounting information (Procházka, 2011). It is also expected to eliminate opportunity to take advantage of gain trading and assets securitization with this resulting to an increase in the quality of financial reporting. Of all the benefits derivable from fair value accounting application, one of the perceived advantages is in its potential to reduce the ease of manipulating accounting numbers (CFA, 2007). There has been a major debate between fair value accounting and historical cost accounting since there have been arguments that historical cost is more reliable and less relevant while fair value is more relevant and less reliable. Unfortunately, relevance and reliability of accounting information are the two fundamental qualities of accounting information as revealed in the works of Ojeka et al. (2016), Schipper (1991) etc. Major opponents of fair value accounting have argued overtime that market based values are to a very large extent free from manipulations and as such can be said to be reliable and since fair value makes use of market values and it can therefore be presumed reliable. This means that fair value has the ability to help eliminate any such opportunity available for management to manipulate earnings while historical cost model, on the other hand, allows firms to prepare and present accounts in such a way that income could easily be managed (Shaffer, 2011). Unfortunately, even though fair value accounting has the ability to eliminate management's tendency of manipulating earnings, it has been argued that only level 1 fair value is free from such manipulations (as they are market value of assets and liabilities from an active liquid market). The same does not hold for Level 2 and 3 fair values as they are subject to manipulations, estimation errors and miscalculations and they are based on management judgment and model estimation. Fair value accounting would have been reliable and useful for decision making if markets for assets and liabilities were liquid and transparent. Unfortunately because several assets and liabilities do not have an active market, subjective and unreliable inputs and methods (based on management's judgment) are used to estimate fair value with this leading to tendency of account manipulations (Bies, 2005). As attested to by Emerson et al. (2010), these manipulations have brought about by the use of managerial judgment can result in the effect that fair value accounting was introduced to eliminate. In spite of the absence of active and liquid market, proponents of fair value accounting believe that fair value accounting is reliable and historical cost accounting can no longer faithfully represent the economic realities of today's complex instruments (Jones, 1988). In a study by Elfaki and Hammad (2015), it was found out that fair value accounting when compared to historical cost accounting enhances reliability of accounting information. According to Fattouh (2016), fair value accounting plays a vital role in enhancing the quality of accounting information embodied in the increment of reliability and appropriateness. This therefore raises a question on whether or not fair value accounting has an association with reliability of accounting information.

Because of this inconsistency and mixed evidence in literature, this study seeks to examine the significant association between fair value accounting and reliability of accounting information of listed firms in Nigeria. The remaining part of this research is organized in four parts. Section 2 comprises a review of extant literatures on fair value accounting and reliability of accounting information. The method employed in proffering solution to the research questions raised is contained in section 3 of this research study while the result of the data obtained and analyzed from the copies of the questionnaire 
distributed is provided in section 4. Conclusion and recommendations are contained in section 5 of this research work.

\section{Literature Review}

\subsection{History of IFRS}

The first step towards International Accounting Standards was the formation of The International Accounting Standards Committee (IASC) in 1973. In 2001, the IASC reorganized and created the International Accounting Standards Board (IASB). The IASB is expected to develop International Financial Reporting Standards (IFRS), which are accounting standards promulgated after 2001, and to enforce the use of each standard (International Accounting Standards Board, 2010). Because of the growth of global markets, the desire of multinational companies for one set of financial statements, and the demand for one common global reporting language, the FASB and the IASB issued the Norwalk Agreement in 2002. This agreement marked their commitment to developing a single set of high-quality standards that would decrease cost, increase efficiency and provide better information for investors (Paul \& Burks, 2010).

In creating IFRSs, the IASB worked with national standard-setters to advance and encourage the adoption of IFRSs through the convergence of National Accounting Standards and IFRSs. IIFRSs set out recognition, measurement, presentation and disclosure requirements dealing with transactions and events and they are important in general financial statements. They may also set out such requirements for transactions and events that arise mainly in specific industries. IFRSs are based on the conceptual framework, which addresses the concepts underlying the information presented in general purpose financial statements. Despite the fact that the conceptual framework was not issued until September 2010, it was produced from the past Framework for the Preparation and Presentation of Financial Statements, which the IASB adopted in 2001.

IFRSs are designed to apply to the general purpose financial statements and other financial reporting of profit-oriented entities. Profit-oriented entities include those engaged in commercial, industrial, financial and similar activities, whether organized in corporate or in other forms. They include organizations such as mutual insurance companies and other mutual co-operative entities that provide dividends or other economic benefits directly and proportionately to their owners, members or participants. Although IFRSs are not designed to apply to not-for-profit activities in the private sector, public sector or government, entities with such activities may find them appropriate. The International Public Sector Accounting Standards Board (IPSASB) prepares accounting standards for governments and other public sector entities, other than government business entities, based on IFRSs. As at today there consists of seventeen IFRS and forty-one IAS, of which some have been superseded. Over, more than 12,000 companies in almost a hundred countries of the world have adopted IFRS. These countries either require or permit IFRS as the basis for financial statement preparation by public companies like in the case of Nigeria.

\subsection{Concept of Fair Value Accounting}

The primary qualities of accounting information are relevance and reliability, the two criteria to enhance the usefulness of the financial report. Fair Value Accounting (FVA), thus, fair value measurements have placed the greater function in financial statements because this information is perceived as more relevant to investors and creditors than historical cost information. In recent years, international standard setters and regulators such as the International Accounting Standards Board (IASB) and the Financial Accounting Standards Board (FASB) have begun to favor the use of Fair Value Accounting over Historical Cost Accounting in financial reporting. A key reason for this shift in methodology is to improve the relevancy of the information contained in financial reports. The general principle underlying the shift is that up-to-date information improves investors' and regulators' abilities to make informed decisions (Kaur, 2013). 
The International Accounting Standard Board (IASB) defines fair value as "an amount at which an asset could be exchanged between knowledgeable and willing parties in arms-length transaction" (IASB 2008). IFRS 13, Fair Value Measurement, sets out a single framework for measuring fair value and provides comprehensive guidance on how to measure it. It is the result of a joint project conducted by the IASB together with FASB, which led to the same definition of fair value as well as an alignment of measurement and disclosure requirements to FAS 157. Both FAS 157 and IFRS 13 define Fair Value "as the price that would be received to sell an asset in an orderly transaction between market participants at the measurement date". This definition of fair value reflects an exit price option, which is the market price from the perspective of a market participant who holds the asset. Moreover, fair value must be a market-based, not an entity-specific measurement, and the firm's intention to hold an asset is completely irrelevant (Betakova et al., 2014). For instance, the application of a blockage factor to a large position of identical financial assets is prohibited given that a decision to sell at a less advantageous price because an entire holding, rather than each instrument individually, is sold represents a factor, which is specific to the firm. If observable market transactions or market information are not directly observable, the objective of fair value measurement still remains the same, that is to estimate an exit price for the asset, and the firm shall use valuation techniques (Betakova et al., 2014). Fair value accounting has turn out to be the preferred option of accounting for financial instruments as against historical cost. The significant explanations behind this inclination are: (a) cost is not relevant or understandable, (b) measuring financial instruments at fair value is practical, (c) fair value eliminates issues which arise from using the cost method, (d) fair value is not overly different to the current practice, and (e) the benefits of fair value are obtainable at a reasonable cost (Hancock, 1996).

However, critics of fair value accounting are concerned that fair value may be less reliable than historical costs since managers may use their discretion to manipulate the information (Ahmad, 2000). As a result of this, investors could be unwilling to base valuation decisions on these subjective estimates (Barth, 1994). It is also view that fair values may increase the volatility of income as compared to historical costs (Barth et al., 1995; Feay \& Abdullah, 2001). For example, in Australia, ED 59 Financial Instruments was criticized by the banking industry, which opposed market value measurement method. The banks were concerned that market value may increase the volatility of earnings (Hancock, 1996).

\subsection{Fair value accounting and Reliability of accounting information}

According to IASB, the main objective of financial reporting is to provide information that is useful to existing and potential investors, lenders and other creditors in making decisions about providing resources to the firm (IASB 2010). Although financial reporting users include large numbers of subjects, both the FASB and IASB focus on the needs of participants in capital markets. This is because investors are considered those who are mostly in need of information from financial reports, given that they cannot usually request information directly from the firm.

The findings of Markou and Tsitsoni (2013) on "Fair Value Accounting and earnings quality" revealed that application of Fair Value Accounting in financial reporting increases the reliability and accuracy of such information provided in the financial statement with this increase leading to effective decision making. Faraj (2012) investigated analytical study of the fair value measurement under accounting standards - A field study. The study asserted that the application of fair value accounting affects the high quality of accounting information. Elfaki and Hammad (2015) carried out a study on "The impact of the application of Fair Value Accounting on the quality of accounting information: An empirical study on a group of companies listed on the Khartoum Stock Exchange". Engaging ANOVA, the findings of the study revealed that Fair Value contributes to the provision of useful information to users of accounting information and help them in decision-making. The study furthermore revealed a positive relationship between fair value application and reliability of accounting information; a positive relationship between the application of fair value accounting and the relevance of accounting information in decision making. Alnajjar (2013) embarked on a study that investigated the impact of 
the application of Fair Value Accounting on the reliability and relevance of the accounting information in Palestinian company's financial statements. By surveying the opinions of external auditors and financial managers of companies in Palestine, the study revealed that the Fair Value Accounting application increases the reliability and relevance of the accounting information in the financial statement. In another study by Fattouh (2016) on "the role of replacing Fair Value Accounting with the principle of historical cost in enhancing the quality of accounting information", the study found out that Fair Value Accounting increased both the reliability and the relevance of accounting information with this making it more useful for users of accounting information in making effective decisions. Alaryan et al. (2014) on the relationship between Fair Value Accounting and presence of manipulation in financial statements. Using the annual reports of forty-five (45) companies during a ten-year period of five years before and five years after the adoption and application of fair value accounting, the result of the study revealed that a higher number of firms manipulated accounting report after the adoption and application of fair value accounting compared to the number of firms before Fair Value adoption. Hence the quality of accounting information is higher before adoption of fair value accounting as compared to after adoption.

\section{Methodology}

The purpose of this study is to examine the association between Fair Value Accounting and reliability of earn accounting information of listed firms in Nigeria. The descriptive research study was adopted for the purpose of this research as this type of research design enables the provision of accurate information on events, situations or persons. It attempts to describe a situation, problem or phenomenon with a view of providing information on them (Olaogun 2008). The quantitative method was adopted as this method is presumed more accurate and precise because of the fact that it develops and tests theories, hypotheses and mathematical models in addition to examining relationships between variables. The respondents for this study were the Capital Market Operators represented by Corporate Investment Analysts and Corporate Portfolio Managers. The Corporate Investment Analysts and Corporate Portfolio Managers were selected as respondents for this study because according to literature (such as Schipper, 1991; Bercel, 1994; Healy \& Palepu, 2001; Clement \& Tse, 2003; Mangena, 2004) they are the principal users of financial statements with this requiring them to have such accounting knowledge that would enable them analyze financial statement for effective and efficient decision making purpose. This group was furthermore selected because they are also primary users of financial accounting information in addition to being representative of other users of accounting information (Oyerinde, 2011). Based on this, it could be reasonably argued that the urge to use a company's financial report is higher for investment analysts and portfolio managers than for any other user (Iyoha, 2011).

The population size for this study includes one hundred and sixty-one respondents decomposed into one-hundred Corporate Investment Analysts and sixty-one Corporate Portfolio Managers. Those in the category of middle/top management staff who are actively involved in the preparation and presentation of the financial statement formed the target audience for the purpose of this study. The floor of the Nigerian Stock Exchange (NSE), Lagos was the main sampling point for the purpose of this study as it is the oldest of all Stock Exchanges in Nigeria. In addition, of a total of 161 Corporate Investment Analysts and Corporate Portfolio Managers, Lagos has the highest number of Corporate Investment Analysts and Portfolio Managers with 149 of them (representing 92.5\%) having their headquarter located in Lagos. The remaining 12 were located outside Lagos State with 9 (representing 5.59\%) having their headquarters located in Abuja, 1 (representing 0.621\%) in Abeokuta, Ogun State, 1(representing $0.621 \%$ ) in Edo State and the last one (representing 0.621\%) has its location in Kano State. The study adopted the census approach (where population size equals the sample size) in determining the sample size. Using the census approach, the sample size was one hundred and sixtyone respondents. 
The study engaged the primary source of data with the research instrument being a survey questionnaire. The questionnaire was divided into two sections; the first section comprised eight items representing one major construct "Reliability". This section focused on such questions that pertain to Fair Value Accounting and reliability of accounting information. The section on the other hand comprised questions on the respondent's bio-data which are (name of organization, sex, age, highest academic qualification, highest professional qualification, job position). The questionnaire was designed using the five-point Likert scale rated 5 (Strongly Agree), 4 (Agree), 3 (Indifference), 2 (Disagree) and 1 (Strongly Disagree). The content validity was engaged for the purpose of ascertaining whether or not the research instrument (the questionnaire) measures what it ought to measure. To engage content validity, the questionnaire was reviewed by experts and independent assessors both within and outside the field of accounting (Okpala, 2012). The Person Product Moment Correlation Technique, a parametric technique used to test the relationship between two variables was used to examine the significant association between Fair Value Accounting and Reliability of accounting information.

\section{Results}

\subsection{Reliability of research instrument}

Table 1

Reliability Statistics

\begin{tabular}{ccc}
\hline Cronbach's Alpha & Cronbach's Alpha Based on Standardized Items & N of Items \\
\hline .800 & .840 & 40
\end{tabular}

Reliability analysis is arrived through the examination of the proportion of systematic variation in a scale. Cronbach alpha is a reliability test for internal consistency since it increases because of an increase in the inter correlations among the items in the analysis. From Table 1 above, the scale items were found to be reliable for the constructs of this research study. The combine reliability of all items in the research instrument gave a reliability statistics of 0.8, which surpasses Pallant's (2005) reliability benchmark of 0.7 .

Table 2

Questionnaire administered and retrieved

\begin{tabular}{lllllll}
\hline S/No & $\begin{array}{l}\text { Respondents } \\
\text { Categories }\end{array}$ & $\begin{array}{l}\text { Total } \\
\text { Distributed }\end{array}$ & $\begin{array}{l}\text { Total } \\
\text { Retrieved }\end{array}$ & $\begin{array}{l}\text { \% Total } \\
\text { Retrieved }\end{array}$ & $\begin{array}{l}\text { Total not } \\
\text { Retrieved }\end{array}$ & $\begin{array}{l}\text { \% Total not } \\
\text { Retrieved }\end{array}$ \\
\hline 1 & Portfolio Managers & 61 & 47 & 77.05 & 14 & 22.95 \\
2 & Investment Analysts & 100 & 95 & 95 & 5 & 5 \\
\hline
\end{tabular}

Source: Field Survey (2017)

Table 2 reveals a breakdown of copies of the questionnaire administered and retrieved from the respondents. One hundred and sixty-one copies of the questionnaire were distributed to the respondents. Of this one hundred and sixty-one, one hundred was given to Corporate Investment Analysts while sixty-one was given to Corporate Portfolio Managers. Out of the one hundred copies of the questionnaire given to Corporate Investment Analysts, ninety-five representing 95\% of the total copies administered was retrieved. Also, of the sixty-one copies of the questionnaire administered to Corporate Portfolio Managers, a total of forty-seven copies of the questionnaire representing $77.05 \%$ of the total copies administered were retrieved thereby leaving the number of total copies retrieved at one hundred and forty-two representing $88.2 \%$ of the total copies administered. Five (5) copies representing $5 \%$ of the one hundred (100) copies administered to Corporate Investment Analysts was not received while fourteen (14) copies representing $22.95 \%$ of the sixty-one (61) copies administered to portfolio managers was not received. This leaves the total of copies of the questionnaire not received at 19 representing $11.8 \%$.

For the purpose of this study, one hypothesis was formulated and stated in the null form: 
$\mathbf{H}_{\mathbf{0}}$ : There is no significant association between Fair Value Accounting and Reliability of accounting information of listed firms in Nigeria.

This hypothesis was tested using the Pearson Product Moment Correlation Technique and the result is stated below:

Table 3

Correlations

\begin{tabular}{|c|c|c|c|c|c|c|c|c|c|}
\hline & & FVA 1 & $\begin{array}{l}\text { Rel 1: } \\
\text { Neutrality }\end{array}$ & FVA2 & FVA 3 & FVA 4 & $\begin{array}{l}\text { Reliability 2: } \\
\text { Faithful Rep }\end{array}$ & $\begin{array}{l}\text { Reliability 3: } \\
\text { Verifiability }\end{array}$ & FVA5 \\
\hline \multirow{3}{*}{$\begin{array}{l}\text { Assets and liabilities that are measured at } \\
\text { fair value do not provide information with } \\
\text { high level of reliability. }\end{array}$} & Pearson Corr & 1 & $.234^{* *}$ & -.127 & .037 & .011 & $-.276^{* *}$ & $.175^{*}$ & -.002 \\
\hline & Sig. (2-tailed) & & .005 & .131 & .660 & .897 & .001 & .037 & .978 \\
\hline & $\mathrm{N}$ & 142 & 142 & 142 & 142 & 142 & 142 & 142 & 142 \\
\hline \multirow{3}{*}{$\begin{array}{l}\text { Accounting information provided in } \\
\text { financial statement prepared on a fair value } \\
\text { accounting basis can be said to be neutral. }\end{array}$} & Pearson Corr & $.234^{* *}$ & 1 & $.258^{* *}$ & $.243^{* *}$ & $.191^{*}$ & .105 & $.186^{*}$ & .145 \\
\hline & Sig. (2-tailed) & .005 & & .002 & .004 & .023 & .215 & .026 & .084 \\
\hline & $\mathrm{N}$ & 142 & 142 & 142 & 142 & 142 & 142 & 142 & 142 \\
\hline \multirow{3}{*}{$\begin{array}{l}\text { By virtue of current market information } \\
\text { provided in the financial statement under } \\
\text { fair value accounting, confidence of users } \\
\text { of accounting information have risen. }\end{array}$} & Pearson Corr & -.127 & $.258^{* *}$ & 1 & $.344^{* *}$ & $.229^{* *}$ & $.316^{* *}$ & .145 & $.169^{*}$ \\
\hline & Sig. (2-tailed) & .131 & .002 & & .000 & .006 & .000 & .084 & .045 \\
\hline & $\mathrm{N}$ & 142 & 142 & 142 & 142 & 142 & 142 & 142 & 142 \\
\hline \multirow{3}{*}{$\begin{array}{l}\text { Information prepared under fair value } \\
\text { accounting basis is to a large extent free } \\
\text { from material errors and bias. }\end{array}$} & Pearson Corr & .037 & $.243^{* *}$ & $.344^{* *}$ & 1 & $.284^{* *}$ & $.378^{* *}$ & .079 & $255^{* *}$ \\
\hline & Sig. (2-tailed) & 660 & .004 & .000 & & .001 & .000 & .351 & .002 \\
\hline & $\mathrm{N}$ & 142 & 142 & 142 & 142 & 142 & 142 & 142 & 142 \\
\hline \multirow{3}{*}{$\begin{array}{l}\text { There is an association between fair value } \\
\text { accounting and reliability of accounting } \\
\text { information. }\end{array}$} & Pearson Corr & .011 & $.191^{*}$ & $.229^{* *}$ & $.284^{* *}$ & 1 & $.435^{* *}$ & -.124 & $.328^{* *}$ \\
\hline & Sig. (2-tailed) & .897 & .023 & .006 & .001 & & .000 & .141 & .000 \\
\hline & $\mathrm{N}$ & 142 & 142 & 142 & 142 & 142 & 142 & 142 & 142 \\
\hline \multirow{3}{*}{$\begin{array}{l}\text { Fair value based financial statement } \\
\text { contains accounting information which is a } \\
\text { representation of reality. }\end{array}$} & Pearson Corr & $-.276^{* *}$ & .105 & $.316^{* *}$ & $.378^{* *}$ & $.435^{* *}$ & 1 & -.074 & $291^{* *}$ \\
\hline & Sig. (2-tailed) & .001 & .215 & .000 & .000 & .000 & & .381 & .000 \\
\hline & $\mathrm{N}$ & 142 & 142 & 142 & 142 & 142 & 142 & 142 & 142 \\
\hline \multirow{3}{*}{$\begin{array}{l}\text { Accounting information in financial } \\
\text { statement prepared using Fair Value } \\
\text { Accounting can be easily verified. }\end{array}$} & Pearson Corr & $.175^{*}$ & $.186^{*}$ & .145 & .079 & -.124 & $\begin{array}{l}.074 \\
-.074\end{array}$ & 1 & -.023 \\
\hline & Sig. (2-tailed) & .037 & .026 & .084 & .351 & .141 & .381 & & .782 \\
\hline & $\mathrm{N}$ & 142 & 142 & 142 & 142 & 142 & 142 & 142 & 142 \\
\hline \multirow{3}{*}{$\begin{array}{l}\text { In all, increases in the relevance of } \\
\text { information provided by financial } \\
\text { statements based on FVA outweigh any } \\
\text { reduction in the reliability of such } \\
\text { information. }\end{array}$} & Pearson Corr & -.002 & .145 & $.169^{*}$ & $.255^{* *}$ & $.328^{* *}$ & $.291^{* *}$ & -.023 & $\frac{1}{1}$ \\
\hline & Sig. (2-tailed) & .978 & 084 & .045 & .002 & .000 & .000 & .782 & \\
\hline & $\mathrm{N}$ & 142 & 142 & 142 & 142 & 142 & 142 & 142 & 142 \\
\hline
\end{tabular}

Table 3 shows the association between fair value accounting and reliability of accounting information. The three sub-properties, sub-characteristics and dimensions to reliability are: verifiability, faithful representation and neutrality. Hence, the first dimension of reliability of accounting information that was statistically tested alongside fair value accounting is neutrality. The results from the table show that there was a correlation effect between fair value accounting and neutrality. Statistically, accounting information provided in financial statements prepared on a fair value accounting basis can be said to be neutral $(\mathrm{r}=0.234, \mathrm{p} \leq 0.01)$. Also, because of current market information provided in the financial statement under fair value accounting, confidence of users of accounting information can be said to have risen $(\mathrm{r}=0.258, \mathrm{p} \leq 0.01)$. There are also statistical evidence to the fact that information prepared under Fair Value Accounting basis is to a large extent free from material errors and bias $(r=0.243, p$ $\leq 0.01)$. Moreover, there was an established association between fair value accounting and reliability of accounting information $(\mathrm{r}=0.191, \mathrm{p} \leq 0.05)$. Furthermore, accounting information in financial statement prepared using Fair Value Accounting can be easily verified $(r=0.186, p \leq 0.05)$.

Another dimension of reliability of accounting information that was used in this study is faithful representation. Statistically, the relationship between fair value accounting and faithful representation was revealed. For example, Table 3 above shows that there was a relationship between faithful representation and the rise in confidence of users of accounting information that are presented using current market information which fair value accounting provides ( $\mathrm{r} 0.316, \mathrm{p} \leq 0.01)$. Moreover, the association between faithful representation and fair value accounting is shown by the extent to which information prepared under fair value accounting basis is free from material errors and bias $(\mathrm{r}=0.378$, $\mathrm{p} \leq 0.01)$. Statistically, it was shown that there is an association between Fair Value Accounting and reliability of accounting information $(r=0.435, p \leq 0.01)$. Generally, Table 3 revealed that increases in the relevance of information provided by financial statements based on Fair Value Accounting outweigh any reduction in the reliability of such information $(r=0.291, p \leq 0.01)$. The third dimension 
of reliability of accounting information used in this research work is verifiability. The results in Table 3 show an association between verifiability and fair value accounting.

Decision: Based on the Pearson Product Correlation tables above, the null hypothesis of "there was no significant association between fair value accounting and reliability of accounting information" was rejected as the Table 3 shows that accounting information under Fair Value Accounting is reliable at the three dimensions (neutrality, verifiability and faithful representation).

\subsection{Discussion of Findings}

Hypothesis 1 stated in its null form states that "There is no significant association between Fair Value Accounting and Reliability of accounting information of listed firms in Nigeria". To test this, Pearson Product Moment Correlation Technique was engaged and as a result, the alternate hypothesis which states that "there is a significant association between Fair Value Accounting and Reliability of accounting information of listed firms in Nigeria" was accepted. This empirical finding is consistent with the result of a research carried out by Fattouh (2016) whose study revealed that FVA plays a vital role in enhancing the quality of accounting information that is embodied in the increment of reliability and appropriateness. The findings of other researchers such as Alnajjar (2013), Elfaki and Hammad (2015) amongst others also revealed a significant association between FVA and Reliability of accounting information

\section{Conclusion and Recommendation}

\subsection{Conclusion}

Traditionally, reliability of accounting information lies on the verifiability of accounting numbers. An explicit factor that motivates the use of fair value is in its perceived ability to reduce the tendency of manipulating accounting numbers. This implies that market based values (which is fair value) are largely (especially level 1 fair value) free from manipulations and as such are highly reliable (CFA Institute, 2007). Although, critics of FVA have capitalized on the fact that only level 1 fair value are free from manipulations while level 2 and 3 which are based on management's discretion are subject to estimation errors and manipulations, Level 2 and 3 fair value estimation and manipulation problem can however be counter measured through an increased disclosure of the underlying assumptions engaged in the course of estimating Fair Value. Fortunately, this increased disclosure requirement has been implemented in the recent IFRS 13 (Fair Value Measurement). In addition, the strength of corporate governance of companies and strong internal control system can also be another countermeasure as according to Song et al. (2010), the strength of corporate governance and internal controls can reduce the problem of less reliable fair value inputs. This point was further stressed when CFA Institute (2007) opined that management through the use of strong corporate governance and internal control system can increase the market's view of the accuracy of their measurements. With this in place, overtime, confidence in such measures will be enhanced. Furthermore, with these measures in place, reliability of accounting information will in no time be enhanced under Fair Value Accounting.

\subsection{Recommendations}

Based on the findings of this study, the following recommendations were made:

1. Regular training programs and conferences on fair value accounting (most importantly the valuation techniques and how to apply them) should be organized for staff of companies. This is because it was observed that most staff of companies in Nigeria do not understand how to appropriately use fair value in an inactive market. Thus, it is of great importance that they are trained as this would help them understand the different valuation and estimation techniques of Fair Value; how and when to apply them in the measurement of assets and liabilities in the financial statement.

2. Because of the high level of subjectivity that comes with using fair value, there is a high tendency that prices can be distorted because of market inefficiencies, liquidity problems or investor's 
irrationality (especially level 3). Thus, there should be an expansion of the disclosure of such accounting information prepared using fair value as this would of course aid user's better understanding on how some assets/liabilities values were arrived at and the valuation technique used. In lieu of this, listed firms should be encouraged and required to engage IFRS 13 (Fair Value Measurement) increased disclosure requirement, as this would enhance user's reliability of accounting information.

\section{Acknowledgements}

The authors would like to thank the anonymous referees for constructive comments on earlier version of this paper.

\section{References}

Ahmad, N. (2000). Fair Value Accounting: Study on relevance and reliability of accounting information (Unpublished Master of Science Dissertation). Universiti Kebangsaan Malaysia, Bangi.

Alaryan, A. L., Haija, A. A. A. \& Alrabei, A. M. (2014). The relationship between fair value accounting and presence of manipulation in financial statements. International Journal of Accounting and Financial Reporting, 4(1), 221-237.

Barth, M. (1994). Fair Value Accounting: Evidence from investment securities and the market valuation of banks. The Accounting Review, 69(1), 1-25.

Barth, M., Landsman, W. \& Wahlen, J. (1995). Effects of bank earnings volatility, regulatory capital, and valuation contractual cash flows. Journal of Banking and Finance, 19, 577-605.

Bercel, A. (1994). Consensus expectations and international equity returns. Financial Analysis Journal, 50, 76-80.

Bies, S. S. (2005). Fair value accounting. Federal Reserve Bulletin, 91, 26-30.

Betakova, J., Hrazdilova Bockova, K. \& Skoda, M. (2014). Fair value usefulness in financial statements. Vienna, Austria: DAAAM International Scientific Book, 433-448

CFA Institute (2007). A comprehensive business reporting model: Financial reporting for investors. New York, NY: CFA Institute.

Clement, M. \& Tse, S. (2003). Do investors respond to analysts' forecast revisions as if forecast accuracy is all that matters? The Accounting Review, 78(1), 227-249

Elfaki, A. and S. Hammad, (2015). The impact of the application of Fair Value Accounting on the quality of accounting information. An empirical study on a group of companies listed on the Khartoum stock exchange. International Journal of Academic Research in Accounting, Finance and Management Sciences, 5(1), 148-160

Faraj, M. (2012). Analytical study of Fair Value Measurement under accounting standards - A field study. Egyptian Journal of Commercial Studies, 36(1)

Fattouh, I. (2016). The role of replacing Fair Value Accounting with the principle of Historical Cost in enhancing the quality of accounting information. IJABER, 14(6), 4931-4950

Feay, W. \& Abdullah, F. (2001). Impact of new derivative disclosures on multinational firms' financing strategies. Multinational Business Review, 9(1), 1-8

Hancock, P. (1996). Financial instruments. Accounting Forum, 19(4), 385-398

Healy, P. \& Palepu, K. (2001). Information asymmetry, corporate disclosure, and the capital markets: A review of the empirical disclosure literature. Journal of Accounting and Economics, 31, 405-440

International Accounting Standard Board (2008). Fair value measurement, where are we in the project? Retrieved $20^{\text {th }} \quad$ November, 2017 from: http://www.iasb.org/Current+Projects/IASB+Projects/Fair+Value+Measurement/Fair+Value+Mea surement.htm

International Accounting Standard Board (2010). Conceptual framework for financial reporting. Retrieved $20^{\text {th }}$ November, 2017 from http://www.iasb.org 
Iyoha, F. (2011). State agencies, industry regulations and the quality of accounting practice in Nigeria (Unpublished doctoral thesis). Covenant University, Ogun State, Nigeria

Jones, J.C. (1988). Financial instruments: Historical cost v. Fair value. The CPA Journal 58(8).

Kaur, J. (2013). The Fairness of the Fair value concept. International Journal of Business and Commerce, 3(3), 1-10.

Mangena, M. (2004). On the perceived importance of disclosure items in UK interim financial report: Evidence from the investment analysts. (Working paper series) Bradford University

Markou, D. \& Tsitsoni, F. (2013). Fair Value Accounting and Earnings Quality: Listed Real Estate Companies in Sweden.

Ojeka, S., Fakile, S., Ani-Jesu, A. and Owolabi, F. (2016). Examining the quality of financial reporting in the banking sector in Nigeria: Does audit committee expertise matter? Journal of Internet Banking, 21(3).

Okere, W., Ogundana, M. O., Adetula, D., Adesanmi, A. D. \& Lawal, Q. O. (2017). Auditor's report and investment decisions in Nigeria: the standpoint of accounting academics. Journal of Management \& Administration, 1(1), 181-195.

Okpala, K. (2012). Adoption of IFRS and financial statements effects: The perceived implications on FDI and Nigeria economy. Australian Journal of Business and Management Research, 2(5), 76-83

Olaogun, J. (2008). Research in behavioural sciences: Concepts, methods and practice. Ikeja, Lagos: Bolabay Publications

Oyerinde, D. (2011). Value relevance of accounting information in the Nigeria Stock Market (Unpublished Doctoral Thesis). Covenant University, Ota, Ogun State, Nigeria

Pallant, J. (2005). SPSS survival manual- A step by step guide to data analysis using SPSS for Windows (Version 12). Australia: Allen \& Unwin,

Paul, A., \& Burks, E. (2010). Preparing for international financial reporting standards. Journal of Finance and Accountancy, 4, 1-8.

Procházka, D. (2011). The role of fair value measurement in the recent financial crunch. Economics, Management

Financial Markets, 6(1), 989-1001

Schipper, K. (1991). Analysts' forecasts. Accounting Horizons, 5(4), 105-121.

Shaffer, S. (2011). Evaluating the Impact of Fair Value Accounting on Financial Institutions: Implication for accounting standards Setting and Bank Supervision. Working Paper No. QAU 1201. Boston: Federal Reserve Bank

Song, C., Thomas, W. \& Yi, H. (2010). Value relevance of FAS No. 157 fair value hierarchy information and the impact of corporate governance mechanisms. The Accounting Review, 85(4), $1375-1410$.

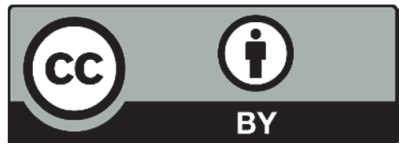

(C) 2019 by the authors; licensee Growing Science, Canada. This is an open access article distributed under the terms and conditions of the Creative Commons Attribution (CC-BY) license (http://creativecommons.org/licenses/by/4.0/). 